may be the solution; but there are difficulties in the way of dividing up a fully international organisation, and the right answer may be close co-operation with existing regional bodies, such as the Pacific Science Council.

Finally, just a few figures about the International Council at the present moment. It has forty-three adhering countries, while the ten Unions have a number of adhering countries ranging from eleven to thirty-seven. It has ten Unions and eleven Joint Commissions; of the ten Unions, five, namely, Astronomy, Geodesy and Geophysies, Chemistry, Physics and Biological Sciences, are General Unions; while the other five, Radio-Science, Geography, Crystallography, Mechanics and History of Sciences, are Specialized Unions. The International Council is one of a small group of non-governmental international organisations that have formal agreements with the United Nations Educational, Scientific and Cultural Organisation, which recognizes it as providing a natural and appropriate form for the international organisation of science. A liaison officer, Dr. R. Fraser, established at Unesco headquarters, assures close co-operation between the two bodies. The president of the International Council is Prof. A. von Muralt, professor of physiology at the University of Berne, and director of the High-Altitude Research Station on the Jungfraujoch.

\section{WATER CONSERVATION IN TERRESTRIAL ARTHROPODS}

A

DISCUSSION on "Water Conservation in Terrestrial Arthropods", arranged by Section D (Zoology) of the British Association, was held in Birmingham on August 31 .

Owing to the small size and relatively large surface area of most arthropods, water conservation is a matter of vital importance, particularly to those species living in dry environments. Indeed, this need is often reflected in the anatomy and physiology of many of their organ systems; for example, in the closing mechanisms of the spiracles, in the digestive and excretory systems and, not least, in the cuticle and egg-shell. Since most attention has recently been focused upon the latter topics, it is natural that the discussion at Birmingham should have been devoted largely to the water-protective properties of arthropod cuticle and egg-shell.

A general introduction on the cuticle was given by Dr. V. B. Wigglesworth, who recalled the main growing-points over the past ten years. The typical hardening and darkening of the insect cuticle which arise from the tanning action of quinones on a watersoluble protein was discovered by M. G. M. Pryor. The process, just as in the tanning of leather, has the further effect of rendering the material hydrophobe and receptive to waxes and other waterproofing agents. A few years previously, J. A. Ramsay had pointed the way to further advances in our understanding of waterproofing mechanisms by his work on the cockroach cuticle. Among other findings he showed that the evapor. ation of water from the cuticle does not vary in a linear manner with the saturation deficit but, owing to a change in the physical properties of a waterproofing grease present at the cuticle surface, increases abruptly at a critical temperature of about $30^{\circ} \mathrm{C}$. This observation was later extended by V. B. Wigglesworth to other insects. Marked specific differences were found ; in general, the more resistant the insect to desiccation, the higher the critical temperature. These variations were in turn related to the variable nature of the cuticular waxes, which were found to have graded properties when extracted. Conclusive evidence that the typical break in the temperature/evaporation curve is indeed due to changes in the properties of the waxes and not to any other component of the cuticle was advanced by J. W. L. Beament, who extracted and deposited the waxes on artificial membranes; the evaporation curves of such membranes showed critical temperatures closely approximating to those of the intact insects from which the waxes were obtained. The more rapid passage of water at the critical temperature is probably caused by a disturbance in the alignment of the wax crystallites owing to thermal agitation.

As a result of these and other studies on the mode of action of solvents and abrasive dusts on the cuticle, a new interpretation of epicuticle structure was proposed. Shown by the light microscope as an apparently uniform membrane, these indirect methods revealed the epicuticle as composite and built up from four very thin superimposed layers of tanned protein (cuticulin), polyphenols, wax and a cementlike covering substance.

Dr. J. W. L. Beament next described his more recent work on the waterproofing mechanisms of insect eggs. After briefly reviewing the remarkable range in size and shape of different eggs, he directed attention to the fundamental structural characters which render compatible the essential functions of mechanical rigidity and ability to hatch, waterconservation and respiration. The insect egg-shell consists of superimposed layers of protein which may be altered by tanning or other processes. All these layers are primarily water-permeable. Like the cuticle, the shell is made waterproof by the deposition of continuous films of wax or oil, although in some examples an existing layer may become impregnated with lipoid. But their arrangement is 'inside out', for the waterproofing layer is usually situated inside the shell and not at the external surface.

Various types of waterproofing systems can be traced. In what is perhaps a primitive condition, as exemplified by the tick egg, the wax is smeared on the outside of the egg by a special waxing organ. In Dixippus and apple sucker eggs, the waterproofing agent is also contributed by the mother and consists of an oily grease incorporated between the layers of the chorion. On the other hand, in such typical eggs as those of the blowfly and aphid, the wax layer is internal and is secreted by the oocyte. In Rhodnius there are two such internal layers laid down at different stages in the development of the egg. Dr. Beament concluded by deseribing the formation of the wax layers in Rhodnius and in the fruit tree red spider mite, both of which possess waterproofing layers of the double type.

It was a particular pleasure to hear Dr. E. H. Slifer, of the University of Iowa, describe her elegant researches on the conservation of water in the egg of the grasshopper Melanoplus differentialis. Here the main point of biological interest centres around the control of water uptake, since this phenomenon is intimately related to the onset and elimination of diapause. The fully formed egg-shell is again a 
multi-layered structure of great complexity. When the egg is laid, the shell consists of the chorion, secreted by the follicle cells of the mother, and, passing inwards, the primary wax layer and vitelline membrane, both secreted by the oocyte. During the first three weeks of development, further layers, the yellow and white cuticles, are in turn added to the inside of the shell by the secretory activities of the embryo. The yellow cuticle is at first porous over the hydropylar region, but becomes impermeable to water at the three-week stage immediately before the onset of diapause. The passage of water through the shell is controlled by the orderly deposition or dissolution of these waterproofing layers. For one week after laying, the entry of water is prevented by the primary wax layer. This barrier is then broken down and water continues to enter the egg until halted by the deposition of the secondary wax layer associated with the yellow cuticle. At the termination of diapause this is in turn broken down, water again enters the egg and embryonic development recommences.

Widely differing powers of limiting evaporation from the cuticle are also found in other groups of terrestrial arthropods, for example, spiders and ticks. In the latter group, as in insects, these differences have been found to be a reflexion of the nature of the cuticular waxes, which vary in efficiency as waterproofing agents from species to species. Dr. A. D. Lees spoke of the probable ecological significance of such differences. The typical ground habitat in a representative series of ticks ranges from moist hill pastures in temperate climates (the sheep tick, Ixodes ricinus) to dry sandy localities in tropical regions (Ornithodoros spp.). The ability to resist desiccation is elosely linked with the available moisture in the environment; the drier the environment the more resistant the species it harbours. The significance of waterproofing efficiency as an ecological factor limiting spread to new environments was illustrated by reference to two species of Ixodes with an overlapping distribution. Owing to its susceptibility to desiccation, $I$. ricinus is prevented from colonizing a relatively dry habitat which is suitable for its better protected relative $I$. canisuga.

The water relations of woodlice, which were discussed by Dr. E. B. Edney, provide several contrasting features. Although they live in a variety of situations ranging from the wet (the littoral species Ligia) to the comparatively dry (Armadillidium), the rate of transpiration through the cuticle, and particularly through that of the pleopods, is always high in comparison with insects. Moreover, the temperature/evaporation curves in all the species examined bear a linear relation to the saturation. deficit and show no break or critical temperature. This evidence, therefore, favours the view that no waterproofing layer is present in the epicuticle. Nevertheless, rapid transpiration may serve a useful purpose under certain conditions. Measurements have shown that evaporation into dry atmospheres can result in a marked fall in the body-temperature. This mechanism, which would be effective in cooling these animals for short periods up to one hour in duration, may enable woodlice to escape the effects of high temperatures. Compared with the Insecta, however, Isopoda have been unsuccessful land colonizers. Two important factors which have limited their distribution on land are, Dr. Edney suggested, their lack of an impermeable cuticle and their low temperature-tolerance.
A. D. LEes

\section{OBITUARIES}

\author{
Sir William Benham, K.B.E., F.R.S.
}

THE death occurred in Dunedin, New Zealand, of Sir William Benham, who for thirty-nine years was professor of biology (later zoology) at the University of Otago, New Zealand. Born at Isleworth, Middlesex, in 1860, he was educated at Marlborough College, being intended for the Indian Civil Service; but later it was decided that he should study for the profession of analytical chemist. Towards this end he went to University College, London, and it was here that he came under the influence of Ray Lankester, who gave the young student great encouragement and finally directed his steps to zoology. In 1883 he graduated B.Sc. (London) and completed his D.Sc. in 1887, his subject being earthworms. After graduating he was sent by Lankester to Kiel to study karyokinesis under Fleming, who was then the leading authority on this new subject; but Benham's interest remained with earthworms, much to Lankester's disappointment. In 1890 he went with Lankester to Oxford, where he remained as Aldrichian demon. strator until he left for New Zealand in 1898.

Benham's first paper on the testis of Limulus was published in the 7 ransactions of the Zoological Society in 1883, the problem being set by Lankester, who was at the time interested in the relation of Limulus to the Arachnida. Another paper on the complete muscular and skeletal systems of Limulus was published before he began his life-work on earthworms. In this he was greatly helped by Jeffrey Bell, of the British Museum, who made available to the young enthusiast a world-wide collection of earthworms.

Although he published more than sixty papers on this group, Benham is equally well known for his publications in other groups. His Part IV of Lankester's "Treatise on Zoology", dealing with Platyhelmia, Mesozoa and Nemertines, is a very valuable book of reference. His account of the British Poly. chætes in the "Cambridge Natural History", published in 1895 , is still the only detailed account of this group in the English language. From time to time he was asked to examine collections of Polychætes-from the Endeavour on the Australian coast, from the Mawson Antarctic Expedition and from the Terra Nova Antarctic Expedition. Benham was especially pleased at being invited to examine the last, in 1921, although he had been living for so many years in the Antipodes.

In New Zealand he kept up his interest in Chætopoda; but he also described representatives of other groups-Balanoglossids, Hirudinea and Gephyræa, and at the other end of the scale he examined whales. living and extinct. Birds, too, the moa and the Notornis, interested him.

Altogether, some hundred and thirty papers were published over a period of sixty-seven years, and some of the figures illustrating these have been reproduced in text-books by English, American, French and German authors. In his retirement he continued his research and kept up a wide correspondence with farmers in connexion with earth. worms and agriculture. His last paper, written in his ninetieth year, is now in the press.

Sir William Benham was a most engaging personality, combining an old-world courtesy with authority and breadth of learning. He was an expert lecturer; even those who had heard many and able lecturers were always refreshed by Benham's approach to his subject and his slightly acid touch. He was 